\title{
Annotations
}

\section{The handicapped school leaver}

The transition from school to adult life can be difficult for many young people. For those with special educational needs it is likely to be a period of particular stress.

A network of provisions exists but it is often difficult to find such provision and in places it is rudimentary, particularly in the provision of suitable day care. It is known, for instance, that the physically handicapped person is under-represented in further education; and that certain teacher training colleges will not consider handicapped students as prospective teachers (what better way of beginning integration?). On the other hand, some universities-such as Sussex-have made strenuous and largely successful efforts to accommodate severely disabled students.

The fact that the school-leaving age has been raised to 16 years for all children means that handicapped children have now lost the extra year that they formerly had over their peers. In comparison, they are often emotionally immature, with fewer social skills (not having been left to go off to the shops or town, and not able to find members of the opposite sex without parental consent). If educated in special schools, they may have spent much of their time dealing with self-care problems and may not have achieved all they were capable of, intellectually.

A single diagnosis-such as cerebral palsy-may bring many functional difficulties (such as spatial problems, poor hand-eye co-ordination) and often, as in spina bifida, a low IQ, which all make placement more difficult. Those with problems of mobility need good dexterity or a good brain to ensure employability, but they often lack both. The ability to stand and move a few steps is of great importance in terms of access at and to work, and should be strenuously encouraged.

In order to define attainable goals and to work towards them in the final years at school, a case conference in the penultimate years, with an occupational therapist and the specialist careers officer, as well as with the usual school and medical staff, is of great value. The acquisition of a job generally implies that (1) the aspirant can cope with his own bodily functions and self care, (2) he can get to his place of employment, (3) he has access to his work, lavatory, and other necessary facilities while there, (4) he has the physical stamina to cope with working an 8-hour day.

On leaving school the child can: (a) Seek entry to Youth Opportunity Programmes. These are very much at a premium for the handicapped, owing both to lack of access facilities and to the increasing competition from able-bodied young unemployed people. (b) He can enter further or higher education, or vocational training. (c) $\mathrm{He}$ can be assessed in industrial surroundings. (d) $\mathrm{He}$ can be placed in sheltered employment. (e) He can enter a local authority training centre/sheltered workshop. (f) $\mathrm{He}$ can have day or residential care. (g) As a young adult he can move from one level to another, but this is not easy. Sadly, he may also slip through the network of provision entirely.

\section{Further education and training}

Higher education. Many universities now have a tutor to the handicapped student and much of the campus is accessible to him. Some courses continue to present particular difficulties to certain groups of the disabled (blind students are rarely enrolled as engineers, for example). The prospective student is advised individually.

Open University. This has been of great benefit to the home-bound student but efforts should first be made to enter him in a full-time university or polytechnic.

Further education. Many local authorities run a year's course for the handicapped school leaver, giving him time to mature, more time to develop independence and social skills, and to build on his present numeracy and literacy. Thereafter it is hoped that the student will be able to integrate with able-bodied peers but problems of access make this rare. Brixton College, London has exceptionally good provisions. Residential colleges of further training include Portland, Hereward, St Loyes, Queen Elizabeth's, Queen Alexandra's colleges; they provide training in skills-such as clerical and engineering work-and they accept the blind. 
Training in independence, basic skills, and general development. I do not pretend to know all sources of help but any student who needs particular help with occupational therapy, independence training, mobility training, or gradual education after leaving school to enable him to use further education courses and other resources may be helped by the Queen Elizabeth Foundation, by local authority ventures such as Fourways in Wigan (there needs to be much more local provision), and by courses run by voluntary organisations (for example, the training given to adolescents with spina bifida at Five Oaks, Ilkley, Yorks., by the Association for Spina Bifida and Hydrocephalus).

Those who are spastic may be assessed while at school and may go to Spastic Society Further Education Colleges. Some eventually find work at Spastic Centres. Children with muscular dystrophy are catered for by the Shaftesbury Society.

\section{Employment}

Direct placement into work. The Specialist Careers Officer, based at the Education Department, interviews the child and his parents before he leaves school and may present him for employment to the employer in much the same manner as the Disablement Resettlement Officer. The Specialist Careers Officer is available to the young person for several years (there is no age limit). Alternatively, after his first job he may present himself to the Disablement Resettlement Officer at the Job Centre.

Sometimes an employer may take a young person under the job introduction scheme for 6 weeks during which time $£ 40$ a week is paid by the Manpower Services Commission. It is hoped that the employer will decide to keep the young person on.

If the young person needs assessment of his skills in relation to industrial work, he may attend the Employment Rehabilitation Centre. This is rarely residential although (for example, at Preston) it can be. This may be a young person's work preparation course (such courses generally last between 6 and 12 weeks). At the end of this a formal assessment is given, and training, or placement is recommended.

\section{Transport (including to work)}

If the young person enters 'open' industry he may be eligible to reimbursement under the Fares to Work Scheme, also provided by the Manpower Services Commission. If he is already in receipt of a mobility allowance this is reduced accordingly. If possible the young person should be taught to use public transport. He or she can now be taught to drive at age 16 years. Adequate energy-conserving (for the patient) mobility will greatly help in the attainment of work. Mobility training is available at Banstead Place (run by the Queen Elizabeth Foundation), and at major British School of Motoring Centres advice is given on adapted cars. Information on mobility and car adaptations is also available from the Mobility Information Service and the Disabled Motorists' Association.

\section{Sheltered employment}

Sheltered employment at less than the rate in open industry (for example 20 minutes an hour at Remploy, with greater productivity yielding bonuses) is available at Remploy and at local authority establishments. Workers tend to be elderly, reflecting the incidence of disability. The Spastics Society and other voluntary organisations run workshops where the rate of pay is up to the maximum allowed by the Department of Health and Social Services.

\section{Day care}

Day care by local authorities may be available although, again, the young person faces the prospect of having the same limited range of facilities from age 16 to 65 and beyond. Those unable to live at home may gain places in Cheshire Homes (often in old country mansions) or in Young Disabled Units (often circumscribed by their placement within the hospital orbit). There are a few pioneer housing facilities with extensive care but considerable freedom, such as that at 48 Boundary Road, Camden Town, London.

M ANNe Chamberlain Department of Rheumatology and Rehabilitation, University of Leeds, Leeds LS2 9PJ 